CLINICAL STUDY

\title{
Decrease in vitamin $D$ receptor and calcium-sensing receptor in highly proliferative parathyroid adenomas
}

\author{
Shozo Yano $^{1,4}$, Toshitsugu Sugimoto ${ }^{1}$, Tatsuo Tsukamoto ${ }^{1}$, Kazuo Chihara ${ }^{1}$, Akira Kobayashi ${ }^{2}$, Sohei Kitazawa ${ }^{3}$, \\ Sakan Maeda ${ }^{3}$ and Riko Kitazawa ${ }^{3}$ \\ ${ }^{1}$ Division of Endocrinology/Metabolism, Neurology, and Hematology/Oncology, Kobe University Graduate School of Medicine, Kobe, Japan, \\ ${ }^{2}$ Kobayashi Clinic, Kobe, Japan, ${ }^{3}$ Division of Molecular Pathology, Kobe University Graduate School of Medicine, Kobe, Japan and \\ ${ }^{4}$ Division of Endocrinology, Diabetes and Hypertension, Brigham and Women's Hospital, Boston, Massachusetts, USA \\ (Correspondence should be addressed to Shozo Yano, Division of Endocrinology, Diabetes and Hypertension, Brigham and Women's Hospital, \\ 221 Longwood Avenue, Boston, Massachusetts 02115, USA; Email: syano@rics.bwh.harvard.edu)
}

\begin{abstract}
Objective: A significant decrease in vitamin D receptor (VDR) and calcium-sensing receptor (CaSR) protein expression has been demonstrated recently in parathyroid (PT) adenomas. In this study, we investigated the relationships between the proliferative activity of parathyroid glands (PTGs) and the expression of VDR as well as CaSR, and compared it with the clinical severity in patients with primary hyperparathyroidism $\left(1^{\circ} \mathrm{HPT}\right)$.

Design: Seven patients with $1^{\circ} \mathrm{HPT}$ were included in this study. Four patients with thyroid carcinoma served as controls.

Methods: Immunohistochemical staining was performed on serial sections of PTGs with specific antibodies against CaSR, VDR, and Ki67. Areas examined in each section were selected at random in relation to the gland size. The number of Ki67-positive cells was expressed as a labeling index (LI; positive cells per 1000 PT cells). The expression of CaSR and VDR was semi-quantitatively analyzed based on the intensity of staining. After averages of the scores from all areas were calculated, CaSR and VDR scores, and Ki67 LI were assigned to each gland for use in statistical analyses.

Results: In PT adenomas, scores of VDR and CaSR were markedly lower than in normal PTGs $(P<0.01)$, while the proportion of Ki67-positive cells in PT adenomas was significantly higher than in normal PTGs $(P<0.01)$. Single regression analyses revealed that Ki67 LI was positively correlated with serum levels of intact parathyroid hormone and $\mathrm{Ca}$, and PTG weight $(\mathrm{R}=0.70$, $P<0.05, \mathrm{R}=0.78, P<0.01$ and $\mathrm{R}=0.84, P<0.05$ respectively). Ki67 LI was negatively correlated with CaSR and VDR scores $(\mathrm{R}=-0.78, P<0.01$ and $\mathrm{R}=-0.72, P<0.05$ respectively). Moreover, there was a strong positive relationship between CaSR and VDR expression $(\mathrm{R}=0.95$, $P<0.001)$.

Conclusions: Marked decreases in VDR and CaSR expression could, at least in part, be responsible for the high proliferation of PT cells and the pathological progression of $1^{\circ} \mathrm{HPT}$.
\end{abstract}

European Journal of Endocrinology 148 403-411

\section{Introduction}

Calcium homeostasis is regulated mainly by parathyroid hormone (PTH) in vertebrates. PTH secretion, in turn, is closely controlled by extracellular calcium (Ca) concentration through the regulatory activity of the calciumsensing receptor (CaSR) (1). Genetic studies have indicated that familial hypocalciuric hypercalcemia $(\mathrm{FHH})$ and neonatal severe hyperparathyroidism (NSHPT) are caused by inactivating mutations of the CaSR gene, and activating mutations lead to autosomal dominant hypoparathyroidism $(2,3)$. Analyses of CaSR gene knockout mice (CaSR $-/-$ and $-/+$ ) have further demonstrated the same phenotypic changes as have been found in NSHPT and FHH respectively (4). In recent studies, CaSR expression in parathyroid glands (PTGs) has been found to be decreased in cases of primary hyperparathyroidism $\left(1^{\circ} \mathrm{HPT}\right)$ and secondary hyperparathyroidism $\left(2^{\circ} \mathrm{HPT}\right)$ that were due to chronic renal failure $(5,6)$. We and others have previously demonstrated that CaSR expression is associated not only with PTH secretion but also with parathyroid (PT) growth potential in $2^{\circ} \mathrm{HPT}(7,8)$. However, it remains to be seen whether the CaSR is also involved in the growth potential of PT adenomas and/or clinical severity in $1^{\circ} \mathrm{HPT}$.

PTH synthesis is negatively controlled by 1,25-dihydroxyvitamin $\mathrm{D}_{3}\left(1,25(\mathrm{OH})_{2} \mathrm{D}_{3}\right)$ through the vitamin $\mathrm{D}$ 
receptor (VDR) $(9,10)$. Point mutations of the VDR gene cause hypocalcemic vitamin D-resistant rickets, also known as type II vitamin D-dependent rickets (11). VDR gene knockout mice have a similar phenotype (12). Vitamin D suppresses not only PTH synthesis at the mRNA level but also PT cell proliferation $(13,14)$. In addition, VDR expression has been shown to be correlated negatively with $\mathrm{PT}$ growth potential in hemodialysis patients with $2^{\circ} \mathrm{HPT}(7,15,16)$. Thus, we hypothesized that VDR expression may have some link to proliferative activity in PT adenomas.

The Ki67 nuclear antigen, a non-histone protein of $345-395 \mathrm{kDa}$, is expressed in all proliferating cells except those in the $G_{0}$ stage (17). The number of Ki67-positive cells per 1000 PT cells (expressed as labeling index; LI) and measurement of the proliferating cell nuclear antigen have been useful indicators of not only proliferative potential but also prognosis in some kinds of neoplasms $(18-20)$.

In the present study, we examined the expression of VDR and CaSR in PT adenomas using immunohistochemical techniques. We have demonstrated a significant decrease in levels of VDR and CaSR proteins in Ki67-positive PT adenomas that affects the proliferative potential of PTGs and the clinical severity of $1^{\circ} \mathrm{HPT}$.

\section{Materials, subjects and methods}

\section{Subjects}

Subjects were patients who had been hospitalized in Kobe University Hospital in 1997-1999 and had undergone parathyroidectomy. Two patients were eliminated from the study because of an increase of serum creatinine $(\mathrm{Cr})$ levels. We selected eleven PTG tissue samples, including seven glands from seven patients with $1^{\circ} \mathrm{HPT}$ and four normal PTGs resected together with thyroid carcinomas from four patients. Four patients with normal levels of serum $\mathrm{Ca}$ and intact PTH (cases 1-4) served as normal controls. Among the seven remaining patients, case 11 had lumbar vertebral fracture, case 9 had ureterolithiasis, and the others (cases 5, 6, 7, 8, and 10) were considered hypercalcemic on the basis of their screening blood test in the absence of specific symptoms. Clinical features and baseline data for these subjects are shown in Table 1.

We also used nine other PTGs for Western blotting. They included four PTGs from four patients with $1^{\circ} \mathrm{HPT}$ (intact PTH levels: 100-200 ng/l) and five PTGs from three hemodialysis patients with $2^{\circ} \mathrm{HPT}$ (intact PTH levels: 1200-2000 ng/l). All subjects described above were operated on between 1997 and 1999 and all gave their informed consent. This study was approved by the Institute Review Board of Kobe University Hospital.

\section{Assay Methods}

Preoperative levels of serum Ca, phosphorus (P), Cr, albumin and ALP were assayed by standard methods. The serum Ca level was corrected with the serum albumin level. The serum intact PTH level was measured using the Allegro Intact PTH radioimmunoassay kit (Nichols Institute Diagnostics, San Juan Capistrano, CA, USA) (21).

\section{Antibodies}

The anti-human CaSR antibody (ADD) kindly provided by Dr Kimbary Rogers (NPS Pharmaceuticals, Salt Lake City, UT, USA) was a mouse monoclonal antibody against residues 214-235 of the human CaSR extracellular domain, as previously described (22). A rat monoclonal anti-human VDR antibody (9A7 $\gamma . E 10 . E 4$; 9A7 $\gamma$ ) and an anti-actin mouse monoclonal antibody were purchased from NeoMarkers (Fremont, CA,

Table 1 PTGs and clinical characteristics in control subjects and patients with $1^{\circ} \mathrm{HPT}$.

\begin{tabular}{|c|c|c|c|c|c|c|c|c|}
\hline Patient no. & $\begin{array}{c}\text { Age } \\
\text { (years) }\end{array}$ & $\begin{array}{l}\text { Histological } \\
\text { diagnosis }\end{array}$ & $\begin{array}{c}\text { Gland weight } \\
(\mathrm{g})\end{array}$ & $\begin{array}{l}\mathbf{s} \mathbf{C a}{ }^{\star} \\
(\mathrm{mM})\end{array}$ & $\begin{array}{c}\mathbf{s} \mathbf{P} \\
(\mathrm{mM})\end{array}$ & $\begin{array}{l}\text { s Cr } \\
(\mu \mathrm{M})\end{array}$ & $\begin{array}{c}\text { ALP† } \\
(\mathrm{U} / \mathrm{I})\end{array}$ & $\begin{array}{c}\text { i PTH† } \\
\text { (ng/l) }\end{array}$ \\
\hline 1 & 69 & Normal & ND & 2.20 & 1.16 & 62 & 304 & 23 \\
\hline 2 & 38 & Normal & ND & 2.15 & 0.94 & 53 & 140 & 32 \\
\hline 3 & 57 & Normal & ND & 2.40 & 1.23 & 71 & 197 & 23 \\
\hline 4 & 52 & Normal & ND & 2.40 & 1.29 & 53 & 241 & ND \\
\hline 5 & 57 & Adenoma & 0.6 & 2.80 & 0.68 & 44 & 558 & 165 \\
\hline 7 & 49 & Adenoma & 0.2 & 2.85 & 1.26 & 53 & 304 & 83 \\
\hline 8 & 72 & Adenoma & 0.4 & 3.08 & 0.97 & 88 & 983 & 234 \\
\hline 9 & 48 & Adenoma & 2.0 & 2.55 & 0.90 & 62 & 233 & 94 \\
\hline 10 & 68 & Adenoma & 3.8 & 2.78 & 0.87 & 62 & 331 & 160 \\
\hline 11 & 48 & Adenoma & 6.2 & 3.55 & 0.77 & 106 & 997 & 904 \\
\hline
\end{tabular}

$\mathrm{ND}=$ not determined. ${ }^{*}$ Serum calcium concentration $(\mathrm{s}$; normal range $2.03-2.60 \mathrm{mM})$. †Total serum alkaline phosphatase (ALP; normal range 100-303 U/l). †Serum intact PTH (i; normal range $10-65 \mathrm{ng} / \mathrm{l})$. 
USA). A rabbit affinity-purified anti-human Ki67 antigen was purchased from DAKO (Glostrup, Denmark).

\section{Immunohistochemistry}

Eleven resected PTGs were fixed with 10\% buffered formalin and embedded in paraffin. The left side of the PTGs were sectioned at $200 \mu \mathrm{m}$ intervals in parallel. At each interval, ten serial $5 \mu \mathrm{m}$ thick sections were made to achieve maximal area. PTG volume was obtained as the product of the average gland profile area in the multiple sections, the number of sections, and the distance between the sections according to the Cavalieri principle (23). The serial sections with the largest PTG area were kept for immunohistochemical study. Additional sections were chosen in PTGs that were more than $10 \mathrm{~mm}$ thick in order to examine them more precisely. Total sections examined were designed to be in proportion to the gland volume. Immunohistochemical staining was performed as previously described (7). Briefly, after deparaffinization and rehydration, sections were incubated with $0.3 \%$ $\mathrm{H}_{2} \mathrm{O}_{2}$ in methanol for $20 \mathrm{~min}$ at room temperature to inactivate the endogenous peroxidase. After extensive washing, sections were processed in distilled $\mathrm{H}_{2} \mathrm{O}$ for 10 min using a medical microwave (MI-77; Higashiya, Tokyo, Japan) at $400 \mathrm{~W}$ for VDR and Ki67 staining. After blocking, sections were incubated overnight at $4^{\circ} \mathrm{C}$, with ADD (diluted 1:1200 in phosphate-buffered saline containing 1\% non-immunized mouse serum), 9A7 $\gamma$ (diluted 1:50), and anti-Ki67 antigen (diluted 1:100), followed by incubation with a biotinylated link secondary antibody (containing anti-rabbit and anti-mouse immunoglobulins) and a peroxidase-labeled streptavidin (DAKO Corp., Carpinteria, CA, USA) for $30 \mathrm{~min}$ each. Final development was carried out with 3,3-diaminobenzidine containing $\mathrm{Ni}^{2+}$ and $\mathrm{Co}^{2+}$ (VDR and Ki67 but not CaSR staining). Slides were then counterstained with hematoxylin for $30 \mathrm{~s}$ for CaSR staining. We took special care regarding the conditions that affect stain intensity, especially the final incubation time. Hematoxylin and eosin (H-E) staining was also performed on each serial slide.

\section{Quantification of immunohistochemical signals}

Semiquantitative analysis of immunohistochemical signals was performed using a modified version of the method described previously (7). In brief, areas for analyses were regularly selected on the H-E stain from every eight areas in each section, according to systematic random sampling (23). Each area was of the same size and the total area examined ( $8-24$ areas) was designed to be in proportion to the total area of the section on the slide. Each slide then underwent light microscopy at a magnification of $\times 200$. Immunoreactivity for CaSR and VDR was semiquantitatively evaluated in each area by a grading scale: grade 3 , more than $75 \%$; grade $2,50-75 \%$; grade $1,25-50 \%$; grade 0 , below 25\% (7). Although normal PTGs contained plenty of fat tissue, evaluation was performed only for chief cells, not for fat cells, endothelial cells, fibroblasts, or blood cells. Ki67-positive cells in each area were counted independent of staining intensity and expressed as Ki67 LI after correction with the chief cell number (positive cells/1000 cells) (18). These quantitative analyses were performed four times.

The results were reproduced by three independent observers (the coefficients of variation, as determined in a previous study using the same method (7), were $3.8,2.7$, and $3.3 \%$ ). Also, there was relatively high agreement among the results obtained by the observers ( $\mathrm{R}$ values were $0.83,0.92$ and 0.86 ). After taking an average of the scores at all areas (minimum 8, maximum 45), CaSR and VDR immunoreactive scores as well as Ki67 LI were assigned to each gland. Using these scores, we performed statistical analyses of the associations among PT cell proliferative activity and expression levels of CaSR and VDR.

\section{Extraction of detergent-soluble proteins from PTG}

Surgically resected PTGs were quickly separated from surrounding fibrous tissue and blood, and minced with fine-tipped scissors. PTGs were resuspended in a lysis buffer ( $1 \%$ Triton X-100, $0.5 \%$ deoxycholate, $0.2 \%$ SDS, $10 \mathrm{mM}$ HEPES, $\mathrm{pH} 7.5,100 \mathrm{mM} \mathrm{NaCl}$, $2 \mathrm{mM}$ EDTA, $1 \mathrm{mM}$ sodium orthovanadate, $1 \mathrm{mM}$ phenylmethylsulfonyl fluoride), containing $20 \mu \mathrm{g} / \mathrm{ml}$ aprotinin and leupeptin. Supernatants were separated by centrifugation $\left(14000 \mathrm{~g}, 4^{\circ} \mathrm{C}\right.$ for $\left.30 \mathrm{~min}\right)$ and subjected to SDS-PAGE and Western blotting.

\section{Western blot analysis}

Proteins separated on $6-15 \%$ polyacrylamide gels were transferred to nitrocellulose filters (MSI Westboro, MA, USA) by electroblotting. After blocking, membranes were incubated with primary antibodies overnight at $4^{\circ} \mathrm{C}$. After washing, immunoblots were visualized using the SuperSignal CL-HRP substrate system (Pierce, Rockford, IL, USA) with horseradish peroxidase-conjugated secondary antibodies (Jackson Laboratories, West Grove, PA, USA).

\section{Statistical analysis}

All data are expressed as means \pm S.E.M. One-way analysis of variance and single regression analyses were performed using Stat View 4.5 (Abacus Concepts, Inc., Berkeley, CA, USA) to assess the linear relationships between study parameters, and Pearson's correlation coefficients were calculated. $P$ values less than 0.05 were considered statistically significant. 


\section{Results}

\section{Proliferative activity of PTGs and clinical manifestations in $1^{\circ} \mathrm{HPT}$}

We first examined the proliferative activity of PT adenoma and normal PT cells with Ki67 immunostaining. Many Ki67-positive cells were observed in PT adenomas from $1^{\circ} \mathrm{HPT}$ patients (Fig. 1a). The staining pattern revealed that Ki67-positive cells were evenly distributed without focal clusters. Although the expression level of Ki67 antigen varied among the PT adenomas, the relatively homogeneous distribution of Ki67-positive cells was likely to be consistent with their monoclonal expansion. On the other hand, we could find few Ki67-positive cells in normal PTGs (Fig. 1d). Results of quantitative analyses of immunoreactivity are shown in Fig. 2. The Ki67 LI was much higher in adenomatous tissue than in normal PTGs. To investigate the association of proliferative activity with the clinical severity of $1^{\circ} \mathrm{HPT}$, we analyzed the relationships between the Ki67 LI and preoperative serum levels of Ca, intact PTH, and total ALP (Fig. 3). The Ki67 LI was positively correlated with intact PTH and Ca levels. The Ki67 LI was significantly correlated with PTG weight as well. A similar relationship was observed between the Ki67 LI and serum ALP level, although it was not statistically significant.

\section{VDR and CaSR expression in PT adenomas}

VDR immunoreactivity, which was detected mainly in the nucleus, was markedly decreased in PTGs from subjects with $1^{\circ} \mathrm{HPT}$, compared with PTGs taken from normal subjects (Fig. 1b and e respectively). Similarly, CaSR expression, which was observed mainly at the cell-cell border, was also decreased in the adenomas (Fig. 1c), compared with normal PTGs (Fig. 1f). These staining patterns were mostly uniform in PT adenomas, while hyperplastic PTGs from $2^{\circ} \mathrm{HPT}$ showed heterogeneous staining intensity of each nodule in the glands, as we described previously (7). In semiquantitative analyses, the expression levels of both CaSR and VDR were significantly lower in the adenomas than in normal PTGs (Fig. 2). We also analyzed the relationships between the expression levels of the receptors and proliferative activity in adenomas and normal PTGs. Single regression analyses revealed that the CaSR and VDR scores had significantly negative correlations with the Ki67 LI (Fig. 4). Interestingly, we found a strong positive correlation between CaSR and VDR scores $(\mathrm{R}=0.949, P<0.001)$ (Fig. 4).
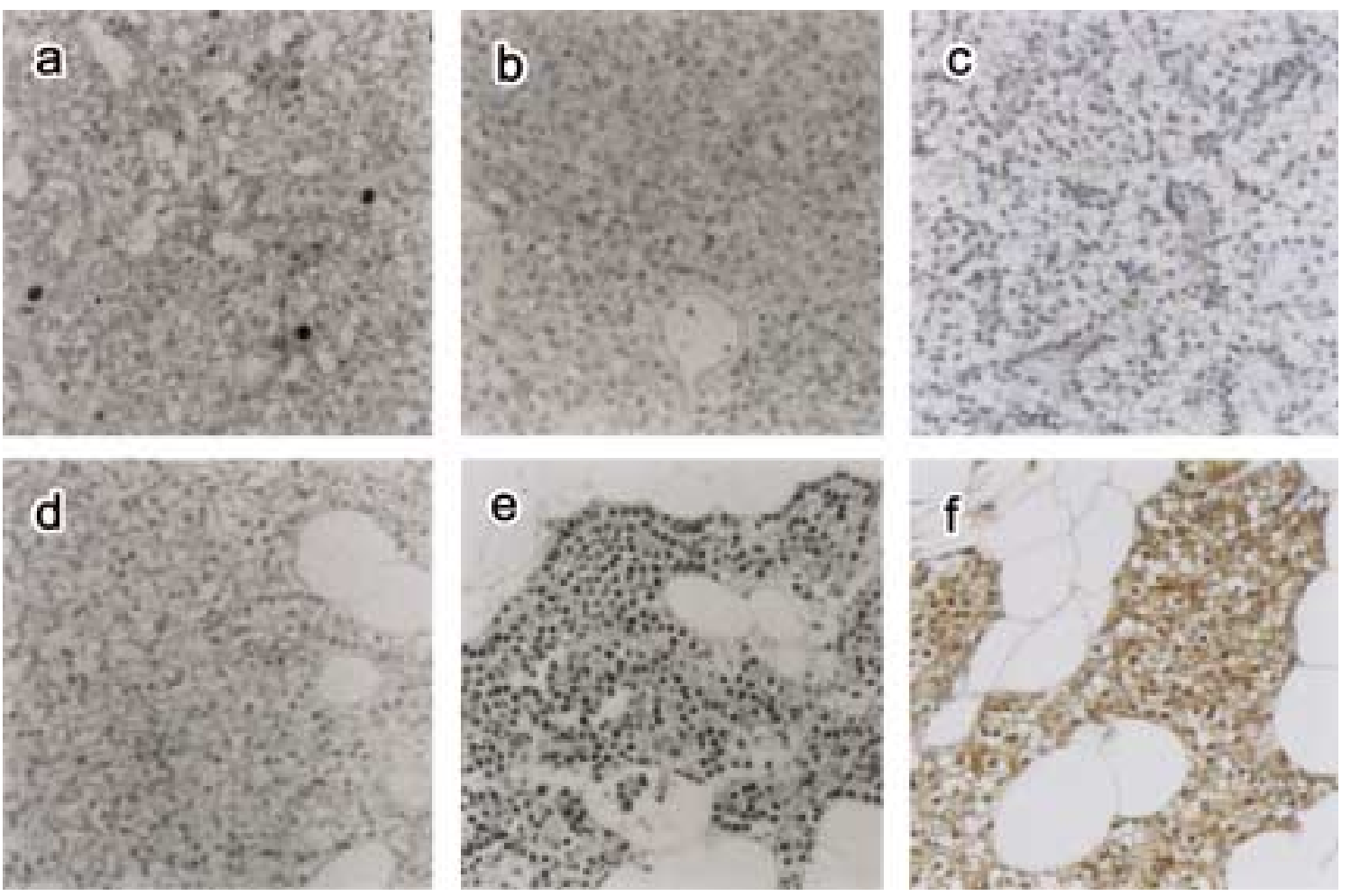

Figure $1 \mathrm{Ki67}$, VDR and CaSR immunohistochemical staining in PT adenoma and normal PTGs. Representative pattern of immunoreactivity for Ki67, VDR, and CaSR as seen in parathyroid adenoma (a, b, and c respectively; $\times 200)$ and in normal PTG (d, e, and $f$ respectively; $\times 200$ ). 

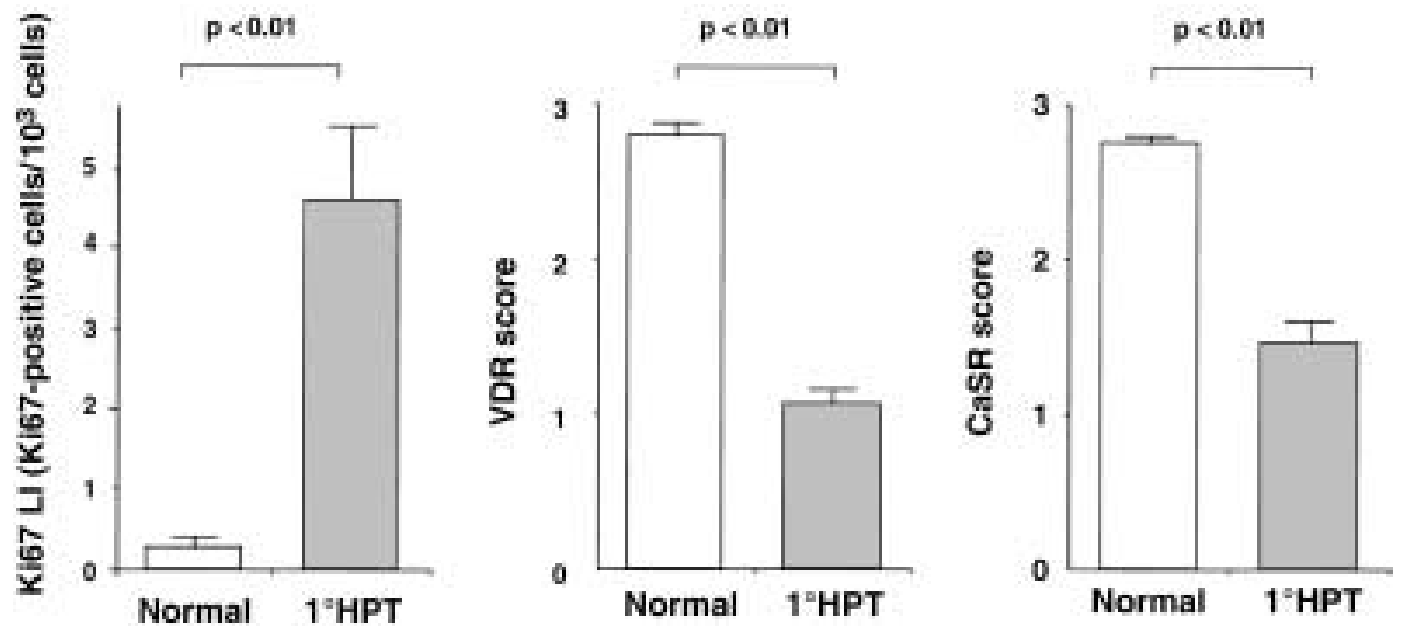

Figure 2 Comparison of Ki67 LI, VDR and CaSR scores in PTG between $1{ }^{\circ} \mathrm{HPT}$ patients and controls. Proliferative activity is expressed as Ki67 LI, and CaSR and VDR scores were obtained after semiquantative analyses as described in Materials, subjects and methods. Values are presented as means \pm S.E.M.

\section{Immunoblot analyses of VDR and CaSR expressions}

We further examined the expression of VDR and CaSR in four PT adenomas taken from patients with $1^{\circ} \mathrm{HPT}$ and compared them with five hyperplastic PTGs from uremic patients. Fifty micrograms of each clarified soluble protein was separated by SDS-PAGE and used for Western blotting. As shown in Fig. 5, CaSR protein was detected at 120,140 , and $160 \mathrm{kDa}$. Higher molecular weight broad bands, which were immunoreactive to ADD antibody, were likely to be oligomers of CaSR in our experimental conditions, as described elsewhere (24). VDR was also identified at about $54 \mathrm{kDa}$, as expected. Notably, the expression levels of VDR and CaSR in PT adenomas appeared to be similar to those found in PTGs from subjects with $2^{\circ} \mathrm{HPT}$. The marked decrease in VDR and CaSR in $2^{\circ} \mathrm{HPT}$ has
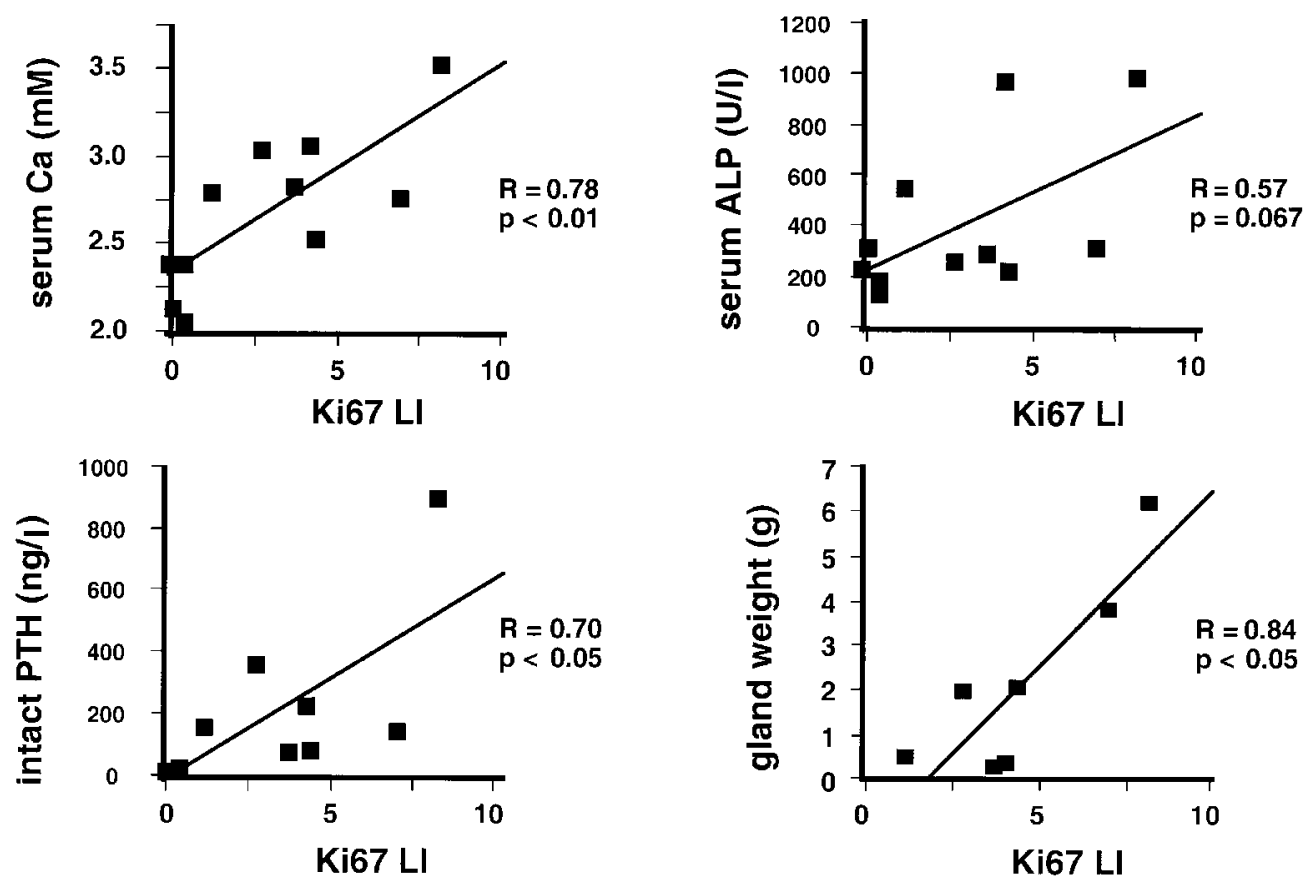

Figure 3 Single regression analyses of Ki67 LI in relation to preoperative levels of serum Ca, PTH and ALP, and PTG weight. Proliferative activity is expressed as Ki67 LI. Ki67 LI had a positive correlation to preoperative serum Ca and PTH. There was a significant relationship between Ki67 LI and PTG weight, as indicated by high coefficients. 

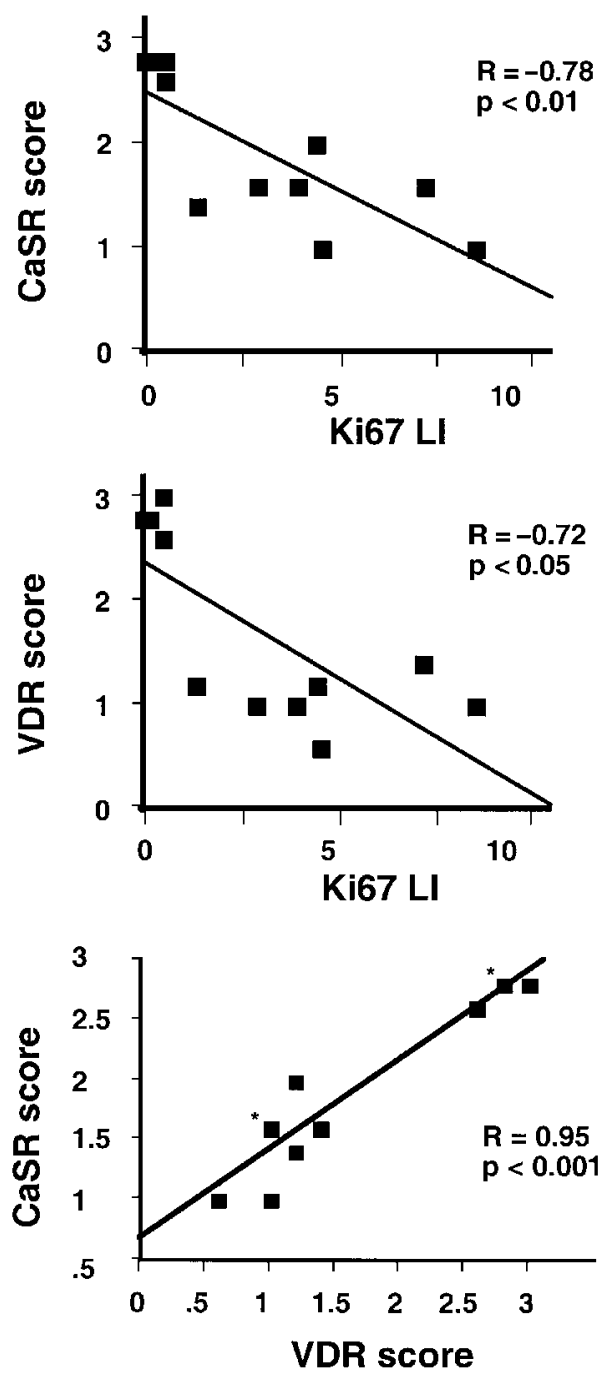

Figure 4 Single regression analyses between Ki67 LI, CaSR and VDR scores in PTGs. Proliferative activity is expressed as Ki67 $\mathrm{LI}$. There was a negative correlation between Ki67 LI and CaSR as well as VDR scores, whereas the CaSR score had a strong positive correlation with VDR score. Asterisks indicate mean two overlapping values.

been demonstrated by us and others $(5-7,16)$; the results shown in Fig. 5 suggest that VDR and CaSR expression could be also reduced in PT adenomas. We could not compare the protein levels in normal PTGs with those in PT adenomas and hyperplastic PTGs using this technique because of the high levels of fat infiltration in normal PTGs.

Taken together, our findings suggested a role of decreased VDR and CaSR expression in the high proliferative potential found in PT adenomas, resulting in a more serious clinical manifestation.

\section{Discussion}

In the present study, we have demonstrated that the high proliferative activity reflected in the Ki67 LI is

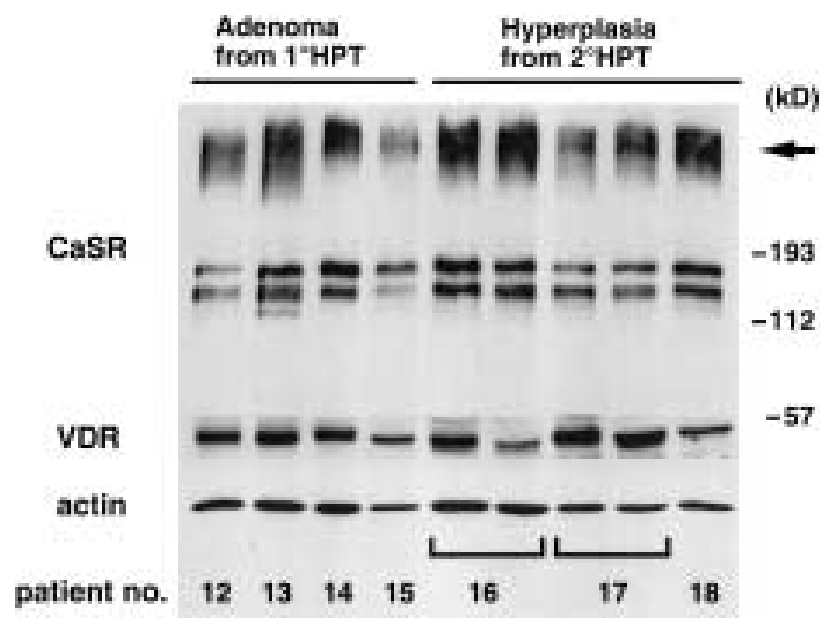

Figure 5 Western blot analyses of CaSR, VDR, and actin proteins in PTGs from $1^{\circ} \mathrm{HPT}$ and $2^{\circ} \mathrm{HPT}$ patients. Lanes $1-4$, PTGs from four $1^{\circ} \mathrm{HPT}$ patients. Lanes 5-9, five PTGs from three $2^{\circ} \mathrm{HPT}$ patients. Patient numbers are given at the bottom of the lanes. Fifty micrograms of protein were applied to each lane. CaSR was detected at 120,140, and $160 \mathrm{kDa}$ with a monoclonal antibody (ADD). Higher molecular weight broad bands (arrow), which reacted to the antibody, were likely to be the oligomers.

closely associated with PTG weight as well as preoperative levels of serum PTH and Ca. These findings suggest that proliferative activity is a strong determinant of both PTG and clinical severity in $1^{\circ} \mathrm{HPT}$, consistent with the results of previous studies (25). In addition, we have also demonstrated that the decrease, not only in CaSR expression but also VDR protein expression in PT adenoma, compared with that found in normal glands, could play some role in the high proliferative activity of PT cells. These findings are also consistent with our previous results that the decrease of expression of both CaSR and VDR was negatively correlated with the proliferative activity of PTGs from subjects with $2^{\circ} \mathrm{HPT}$ due to chronic renal failure (7). Thus, our results may be interpreted as strong confirmation of previous reports on the growth potential of PT adenomas $(26,27)$. The Ki67 LI in our study was higher than that in a previous study (19). This can be explained by the characteristics of the patients examined. As shown in Table 1, our patients had moderate to severe diseases, while Parfitt et al. (19) took account of non-biased random sampling.

Although we know that CaSR expression decreases in highly proliferative PT adenomas $(5,28)$, the mechanisms remain unclear. Mutations and deletions of the coding region in the CaSR gene do not seem to be involved in this decrease $(29,30)$. The CaSR gene has been demonstrated to have vitamin D-responsive elements (VDREs) in the $5^{\prime}$-flanking region and to be regulated by $1,25(\mathrm{OH})_{2} \mathrm{D}_{3}$ through binding the complex of $1,25(\mathrm{OH})_{2} \mathrm{D}_{3}$ with VDR to VDREs (31), as has been suggested by an in vivo study of a renal failure model (32). Taken together with our finding of a significant 
correlation between CaSR and VDR protein levels, decreased CaSR expression in PT adenoma could be due to low VDR protein levels. Indeed, we showed a significant decrease in VDR protein in PT adenomas, consistent with other studies using RNase protection assays and immunohistochemistry $(33,34)$. Although the binding assay detected no significant differences in VDR concentration between affected PTGs and controls in $1^{\circ} \mathrm{HPT}(35)$, such a negative finding might be based on the limitations of this method. In PTGs from subjects with $2^{\circ} \mathrm{HPT}$ due to chronic renal failure, VDR expression levels have been found to be much lower than those of normal controls and also to be inversely related to proliferative activity $(7,16,36)$. Our Western blot analyses showed that VDR expression levels in PT adenomatous tissue from subjects with $1^{\circ} \mathrm{HPT}$ were similar to those in hyperplastic PTGs from subjects with $2^{\circ} \mathrm{HPT}$. This similarity is consistent with our immunohistochemical findings, in which the VDR expression level was much lower in PTGs taken from subjects with $1^{\circ} \mathrm{HPT}$ than in normal PTGs. In contrast, a significant decrease (assessed by saturation binding assay) in VDR levels in PTGs from subjects with $2^{\circ} \mathrm{HPT}$ (compared with those taken from subjects with $1^{\circ} \mathrm{HPT}$ ) has been reported (15). Since PTG size was not described by Korkor (15), this discrepancy might be explained by gland size as well as methodological differences. PTGs used for the binding assay (15) were likely very large, judging from the serum intact PTH levels (means \pm s.D.; $8000 \pm 5600 \mathrm{pg} / \mathrm{ml}$ ). VDR content in PTGs from subjects with $2^{\circ} \mathrm{HPT}$ tends to decrease with gland size (our unpublished data). Therefore, our findings would not be contradictory compared with previous results.

The regulatory mechanism of VDR expression has been studied. Some works suggest the existence of an organ-specific mechanism (37-39), and others demonstrate $1,25(\mathrm{OH})_{2} \mathrm{D}_{3}$-induced up-regulation of VDR in kidney, intestine, and osteoblast-like cells (37, 40, 41 ), although such regulations in PTGs are controversial $(38,42,43)$. In renal failure, several possible mechanisms have been proposed for VDR down-regulation, such as low plasma $1,25(\mathrm{OH})_{2} \mathrm{D}_{3}$ concentration (37), accumulation of uremic toxin (44), and/or high levels of plasma PTH (45). As VDR expression in PTGs decreased in both $1^{\circ} \mathrm{HPT}$ and $2^{\circ} \mathrm{HPT}$, as shown in the present study, it seems unlikely that plasma concentrations of $1,25(\mathrm{OH})_{2} \mathrm{D}_{3}, \mathrm{Ca}$, or $\mathrm{P}$ are responsible for VDR down-regulation, as previously suggested (33). Somatic mutations of the coding region of the VDR gene do not often seem to contribute to the primary pathogenesis of PT adenomas (46). Therefore, possible mechanisms of VDR down-regulation may involve the decreased stability of VDR mRNA or protein and the increased methylation of the VDR gene following inhibition of its transcription (34). Further investigation is required to elucidate the regulatory mechanisms of VDR expression in PTGs.
Under some circumstances, VDR and CaSR can play crucial roles in the regulation of PT growth. Sufficient $1,25(\mathrm{OH})_{2} \mathrm{D}_{3}$ suppresses not only PTH synthesis at the mRNA level but also PT cell proliferation through the VDR $(13,14)$. Previous work also indicates the involvement of VDR down-regulation in the high proliferative activity of PTGs in $2^{\circ} \mathrm{HPT}$ (16). Also loss of function or genetic ablation of CaSR leads to PT hyperplasia $(2-4)$. In addition, in vivo administration of CaSR agonists (calcimimetics) has resulted in the prevention of PTG growth in a rat renal failure model (47). We recently demonstrated an association between decreased expression of CaSR and high growth potential of PTGs from patients with $2^{\circ} \mathrm{HPT}$ caused by chronic renal failure (7). In the present study, we have demonstrated that similar associations exist in PT adenomas from patients with $1^{\circ} \mathrm{HPT}$. Thus, decreased expression of VDR and CaSR may affect PTG growth not only in $2^{\circ} \mathrm{HPT}$ but also in $1^{\circ} \mathrm{HPT}$. On the other hand, we could not find significant correlations between VDR or CaSR expression and PTG weight as well as serum levels of $\mathrm{Ca}, \mathrm{P}, \mathrm{PTH}$, and ALP in patients with $1^{\circ} \mathrm{HPT}$. These findings are compatible with previous work, in which expression of neither VDR nor CaSR is directly related to the clinical severity of $1^{\circ} \mathrm{HPT}$ (34). Additionally, in patients with $2{ }^{\circ} \mathrm{HPT}$, there are no relationships between VDR mRNA levels and serum PTH, Ca, or glandular weight (33). However, marked decreases in levels of these receptors are, at least to some degree, involved in the high growth and hormone-secreting potential of PT cells, subsequently inducing a greater mass of PT adenoma as well as more severe clinical status of $1^{\circ} \mathrm{HPT}$. Since calcimimetics have been shown to be useful for medical treatment of $1^{\circ} \mathrm{HPT}$ (48), these agents would be likely to suppress PTH secretion and perhaps even proliferation through enhancing the CaSR signaling.

In conclusion, we have demonstrated decreased expression of VDR and CaSR proteins in PT adenomas compared with normal PTGs. Such differences could contribute to the high proliferative activity of PT cells and the pathological progression of $1{ }^{\circ} \mathrm{HPT}$.

\section{Acknowledgements}

We thank all the members of our laboratory for helpful discussions and Mr M Okamoto and Mr H Fujisawa for the rapid transport of PTG samples. This study was supported in part by a Grant-in-Aid from the Hormone Receptor Abnormality Research Committee, Ministry of Health and Welfare of Japan, and by the Research Society for Metabolic Bone Disease.

\section{References}

1 Brown EM, Gamba G, Riccardi D, Lombardi M, Butters R, Kifor O et al. Cloning and characterization of an extracellular $\mathrm{Ca}^{(2+)}$ sensing receptor from bovine parathyroid. Nature $1993 \mathbf{3 6 6}$ $575-580$. 
2 Pollak MR, Brown EM, Chou YH, Hebert SC, Marx SJ, Steinmann B et al. Mutations in the human $\mathrm{Ca}^{(2+)}$-sensing receptor gene cause familial hypocalciuric hypercalcemia and neonatal severe hyperparathyroidism. Cell 199375 1297-1303.

3 Pearce SH, Williamson C, Kifor O, Bai M, Coulthard MG, Davies M et al. A familial syndrome of hypocalcemia with hypercalciuria due to mutations in the calcium-sensing receptor. New England Journal of Medicine 1996335 1115-1122.

4 Ho C, Conner DA, Pollak MR, Ladd DJ, Kifor O, Warren HB et al. A mouse model of human familial hypocalciuric hypercalcemia and neonatal severe hyperparathyroidism. Nature Genetics 199511 389-394.

5 Kifor O, Moore F Jr, Wang P, Goldstein M, Vassilev P, Kifor I et al. Reduced immunostaining for the extracellular $\mathrm{Ca}^{(2+)}$-sensing receptor in primary and uremic secondary hyperparathyroidism. Journal of Clinical Endocrinology and Metabolism $1996 \mathbf{8 1}$ $1598-1606$.

6 Gogusev J, Duchambon P, Hory B, Giovannini M, Goureau Y, Sarfati E et al. Depressed expression of calcium receptor in parathyroid gland tissue of patients with hyperparathyroidism. Kidney International $1997 \mathbf{5 1} 328-336$.

7 Yano S, Sugimoto T, Tsukamoto T, Chihara K, Kobayashi A, Kitazawa $\mathrm{S}$ et al. Association of decreased calcium-sensing receptor expression with proliferation of parathyroid cells in secondary hyperparathyroidism. Kidney International $2000 \mathbf{5 8}$ 1980-1986.

8 Brown AJ, Ritter CS, Finch JL \& Slatopolsky EA. Decreased calcium-sensing receptor expression in hyperplastic parathyroid glands of uremic rats: role of dietary phosphate. Kidney International $1999551284-1292$.

9 Silver J, Russell J \& Sherwood LM. Regulation by vitamin D metabolites of messenger RNA for pre-proparathyroid hormone in isolated bovine parathyroid cells. PNAS $1985 \mathbf{8 2} 4270-4273$.

10 Okazaki T, Igarashi T \& Kronenberg HM. 5'-Flanking region of the parathyroid hormone gene mediates negative regulation by 1,25- $(\mathrm{OH})_{2}$ vitamin $\mathrm{D}_{3}$. Journal of Biological Chemistry 1988 $2632203-2208$

11 Hughes MR, Malloy PJ, Kieback DG, Kesterson RA, Pike JW, Feldman D et al. Point mutations in the human vitamin D receptor gene associated with hypocalcemic rickets. Science $19882421702-1705$.

12 Yoshizawa T, Handa Y, Uematsu Y, Takeda S, Sekine K, Yoshihara Y et al. Mice lacking the vitamin D receptor exhibit impaired bone formation, uterine hypoplasia and growth retardation after weaning. Nature Genetics 199716 391-396.

13 Kremer R, Bolivar I, Goltzman D \& Hendy GN. Influence of calcium and 1,25-dihydroxycholecalciferol on proliferation and proto-oncogene expression in primary cultures of bovine parathyroid cells. Endocrinology 1989125 935-941.

14 Szabo A, Merke J, Beier E, Mall G \& Ritz E. 1,25(OH $)_{2}$ vitamin $\mathrm{D}_{3}$ inhibits parathyroid cell proliferation in experimental uremia. Kidney International $1989351049-1056$.

15 Korkor $\mathrm{AB}$. Reduced binding of $\left[{ }^{3} \mathrm{H}\right] 1,25$-dihydroxyvitamin $\mathrm{D}_{3}$ in the parathyroid glands of patients with renal failure. New England Journal of Medicine 1987316 1573-1577.

16 Fukuda N, Tanaka H, Tominaga Y, Fukagawa M, Kurokawa K \& Seino Y. Decreased 1,25-dihydroxyvitamin $\mathrm{D}_{3}$ receptor density is associated with a more severe form of parathyroid hyperplasia in chronic uremic patients. Journal of Clinical Investigation 1993 92 1436-1443.

17 Gerdes J, Li L, Schlueter C, Duchrow M, Wohlenberg C, Gerlach C et al. Immunobiochemical and molecular biologic characterization of the cell proliferation-associated nuclear antigen that is defined by monoclonal antibody Ki-67. American Journal of Pathology 1991138 867-873.

18 Wang Q, Palnitkar S \& Parfitt AM. Parathyroid cell proliferation in the rat. Effect of age, and of phosphate administration and recovery. Endocrinology $19961374558-4562$.

19 Parfitt AM, Wang Q \& Palnitkar S. Rates of cell proliferation in adenomatous, suppressed and normal parathyroid tissue: implications for pathogenesis. Journal of Clinical Endocrinology and Metabolism $1998 \mathbf{8 3} 863-869$.

20 Kamel OW, LeBrun DP, Davis RE, Berry GJ \& Warnke RA. Growth fraction estimation of malignant lymphomas in formalin-fixed paraffin-embedded tissue using anti-PCNA/cyclin 19A2. Correlation with Ki-67 labeling. American Journal of Pathology 1991 138 1471-1477.

21 Frolich M, Walma ST, Paulson C \& Papapoulos SE. Immunoradiometric assay for intact human parathyroid hormone: characteristics, clinical application and comparison with a radioimmunoassay. Annals of Clinical Biochemistry 199027 69-72.

22 Goldsmith PK, Fan G, Miller JL, Rogers KV \& Spiegel AM. Monoclonal antibodies against synthetic peptides corresponding to the extracellular domain of the human $\mathrm{Ca}^{(2+)}$ receptor: characterization and use in studying concanavalin A inhibition. Journal of Bone and Mineral Research 199712 1780-1788.

23 Gundersen HJG, Bendtsen TF, Korbo L, Marcussen N, Moller A, Nielsen $\mathrm{K}$ et al. Some new, simple and efficient stereological methods and their use in pathological research and diagnosis. Acta Pathologica, Microbiologica et Immunologica Scandinavica $198896379-394$.

24 Bai M, Trivedi S \& Brown EM. Dimerization of the extracellular calcium-sensing receptor (CaR) on the cell surface of CaR-transfected HEK293 cells. Journal of Biological Chemistry 1998273 23605-23610.

25 Lloyd HM, Jacobi JM, Willgoss D, Kearney J \& Ward P. DNA synthesis and secretory activity in parathyroid adenomas. Acta Endocrinologica $19819670-74$.

26 Loda M, Lipman J, Cukor B, Bur M, Kwan P \& DeLellis RA. Nodular foci in parathyroid adenomas and hyperplasias: an immunohistochemical analysis of proliferative activity. Human Pathology 199425 1050-1056.

27 Tominaga Y, Tsuzuki T, Uchida K, Haba T, Otsuka S, Ichimori T et al. Expression of PRAD1/cyclin D1, retinoblastoma gene products, and Ki67 in parathyroid hyperplasia caused by chronic renal failure versus primary adenoma. Kidney International $1999551375-1383$.

28 Farnebo F, Hoog A, Sandelin K, Larsson C \& Farnebo LO. Decreased expression of calcium-sensing receptor messenger ribonucleic acid in parathyroid adenomas. Surgery $1998 \mathbf{1 2 4}$ 1084-1098.

29 Hosokawa Y, Pollak MR, Brown EM \& Arnold A. Mutational analysis of the extracellular $\mathrm{Ca}^{(2+)}$-sensing receptor gene in human parathyroid tumors. Journal of Clinical Endocrinology and Metabolism $1995 \mathbf{8 0} 3107-3110$.

30 Cetani F, Pinchera A, Pardi E, Cianferotti L, Vignali E, Picone A et al. No evidence for mutations in the calcium-sensing receptor gene in sporadic parathyroid adenomas. Journal of Bone and Mineral Research $19996878-882$.

31 Canaff L \& Hendy GN. Human calcium-sensing receptor gene: vitamin D response elements in promoters P1 and P2 confer transcriptional responsiveness to 1,25-dihydroxyvitamin D. Journal of Biological Chemistry 2002277 30337-30350.

32 Brown AJ, Zhong M, Finch J, Ritter C, McCracken R, Morrissey J et al. Rat calcium-sensing receptor is regulated by vitamin $\mathrm{D}$ but not by calcium. American Journal of Physiology $1996 \mathbf{2 7 0}$ F454-F460.

33 Carling T, Rastad J, Szabo E, Westin G \& Akerstrom G. Reduced parathyroid vitamin D receptor messenger ribonucleic acid levels in primary and secondary hyperparathyroidism. Journal of Clinical Endocrinology and Metabolism 2000 85 2000-2003.

34 Rao DS, Han ZH, Phillips ER, Palnltkar S \& Parfitt AM. Reduced vitamin D receptor expression in parathyroid adenomas: implications for pathogenesis. Clinical Endocrinology 200053 373-381.

35 Trydal T, Varhaug JE, Myking A, Aksnes L, Aakvaag A \& Aarskog D. Serum vitamin D metabolites and calcitriol receptor concentration in parathyroid tissue in primary hyperparathyroidism. Acta Endocrinologica 1992127 407-412.

36 Koike T, Fukuda N, Fukagawa M, Ohta K \& Kurokawa K. Correlation of enhanced cell proliferation with decreased density 
of vitamin D receptor in parathyroid hyperplasia in chronic dialysis patients. Nephrology $19973279-284$.

37 Costa EM \& Feldman D. Homologous up-regulation of the $1,25(\mathrm{OH})_{2}$ vitamin $\mathrm{D}_{3}$ receptor in rats. Biochemical and Biophysical Research Communications 1986137 742-747.

38 Brown AJ, Zhong M, Finch J, Ritter C \& Slatopolsky E. The roles of calcium and 1,25-dihydroxyvitamin $\mathrm{D}_{3}$ in the regulation of vitamin D receptor expression by rat parathyroid glands. Endocrinology $19951361419-1425$.

39 Sriussadaporn S, Wong MS, Pike JW \& Favus MJ. Tissue specificity and mechanism of vitamin $D$ receptor up-regulation during dietary phosphorus restriction in the rat. Journal of Bone and Mineral Research $199510271-280$.

40 Strom M, Sandgren ME, Brown TA \& DeLuca HF. 1,25-dihydroxyvitamin $D_{3}$ up-regulates the 1,25-dihydroxyvitamin $D_{3}$ receptor in vivo. PNAS $1989869770-9773$.

41 van Leeuwen JP, Birkenhager JC, van Wijngaarden VT, van den Bemd GJ \& Pols HA. Regulation of 1,25-dihydroxyvitamin $D_{3}$ receptor gene expression by parathyroid hormone and cAMP-agonists. Biochemical and Biophysical Research Communications $1992 \mathbf{1 8 5} 881-886$.

42 Brown AJ, Berkoben M, Ritter C \& Slatopolsky E. Binding and metabolism of 1,25-dihydroxyvitamin $\mathrm{D}_{3}$ in cultured bovine parathyroid cells. Endocrinology $1992130276-281$.

43 Naveh MT, Marx R, Keshet E, Pike JW \& Silver J. Regulation of 1,25-dihydroxyvitamin $\mathrm{D}_{3}$ receptor gene expression by 1,25-dihydroxyvitamin $\mathrm{D}_{3}$ in the parathyroid in vivo. Journal of Clinical Investigation 1990 86 1968-1975.

44 Hsu CH, Patel RS \& Vanholder R. Mechanism of decreased intestinal calcitriol receptor concentration in renal failure. American Journal of Physiology 1993264 F662-F669.

45 Reinhardt TA \& Horst RL. Parathyroid hormone down-regulates 1,25-dihydroxyvitamin D receptors (VDR) and VDR messenger ribonucleic acid in vitro and blocks homologous up-regulation of VDR in vivo. Endocrinology $1990127942-948$.

$46 \mathrm{Wu} \mathrm{H}$ \& Arnold A. Vitamin D receptor gene as a candidate tumor suppressor gene in parathyroid adenomas. Journal of Bone and Mineral Research 199611 S488 (Abstract).

47 Wada M, Furuya Y, Sakiyama J, Kobayashi N, Miyata S, Ishii H et al. The calcimimetic compound NPS R-568 suppresses parathyroid cell proliferation in rats with renal insufficiency: control of parathyroid cell growth via a calcium receptor. Journal of Clinical Investigation $1997 \mathbf{1 0 0} 2977-2983$.

48 Silverberg SJ, Bone HG III, Marriott TB, Locker FG, Thys-Jacobs S, Dziem G et al. Short-term inhibition of parathyroid hormone secretion by a calcium-receptor agonist in patients with primary hyperparathyroidism. New England Journal of Medicine 1997 337 1506-1510.

Received 11 September 2002

Accepted 3 January 2003 